\title{
The Power of Reputation: A Case Study on Artistic Directors of Austria's Music Festivals
}

\author{
Martina Kalser-Gruber* \\ The Archives of Contemporary Arts, University of Continuing Education Krems
}

Received November 23, 2020; Accepted June 28, 2021

\begin{abstract}
Reputation represents the standing of a person or organisation in the public field and illustrates/marks their contribution towards the implementation of collectively shared values and goals. From a business point of view, reputation belongs to the intangible assets of a company and is therefore part of the goodwill. Especially, the leader of an organisation—particularly in a cultural enterprise-shapes the external public image of the organisation, studies the impact of the image on the public consciousness by assessing public opinion about the organisation's achievements and consequently also gauges the economic and/or artistic success of the organisation. Based on the statements of experts about music festivals of high culture in Austria alongside the big players such as Salzburg or Bregenz Festival, the aim of this paper is to investigate the relationship between reputation of artistic directors (ADs) and the performance of cultural enterprises. It will also be demonstrated how the reputation of these individuals has an impact on tourism, hospitality and trade in the vicinity of cultural enterprises.
\end{abstract}

Keywords: artistic director • cultural operations • reputation • performance • artistic quality

\section{Introduction}

The meaning of reputation is multi-layered and much more than just image. It plays a major role in every economic sector and functions as the central control variable for organisational action and public relations (PR) (Eisenegger \& Imhof 2009: 243; Fombrun et al. 2000: 241f; Herbst 2003a: 71; Hoffjann 2015: 181). In particular, an organisation's leader shapes the external public image of the organisation and ascertains the impact of the image on organisational performance; the leader also gauges the manner and extent of influence of public opinion on organisational performance; this is applicable especially in the non-profit sector of culture (Abfalter 2010: 345 ), 'where an organisation's reputation is "the currency" by which it trades in the market-place' (Wood \& Rentschler 2003: 528; Fombrun et al. 2000).

This paper deals with the topic of reputation management in the cultural field and thus offers an essential theoretical basis. In the following, the term reputation is first defined, before the reputation of companies (corporate reputation) and, in particular, the reputation of individuals (personal reputation) is given special attention. The focus is directed towards the artistic director $(A D)$. Since smaller and younger music festivals in Austria will be examined, the format of the festival and the specifics of festival communication will be demonstrated. Additionally, the term success is explained.

Finally, it will be determined to what extent the AD's reputation has an impact on the economic and/or artistic success of cultural enterprises. Also, the risk of an AD's negative reputation will be pointed out.

\footnotetext{
*E-mail: Martina.kalser-gruber@donau-uni.ac.at
} 


\section{Reputation}

Since reputation generally fulfils essential tasks for organisations, it serves as a fundamental control parameter for PR and organisational action (Eisenegger \& Imhof 2009: 243). According to Eisenegger and Imhof, the concept of reputation-derived from the Latin word reputation (consideration, calculation)—has had a remarkable career both in practice and in communication studies (2007: 1), but, for a long time, there was no interdisciplinary recognised definition (Bromley 2002: 35). While sociologists interpret the term (too) broadly and see reputation as a communicatively conveyed form of recognition or disdain (Eisenegger \& Imhof 2007: 1; cf. Shrum \& Wuthnow 1988: 882), the definitions from PR and marketing will soon be much more operationalisable. Fombrun defines reputation as 'overall estimation of a firm by its stakeholders, which is expressed by the net affective reactions of customers, investors, employees, and the general public' (1996: 78f). This is also proven by Hall, who, in his 1992 study, found that corporate reputation is actually the most important intangible asset in competition with other companies (p. 141). Ebbers and Wijnberg also refer to a socio-theoretical component, because reputation plays a role in decision-making processes, even when the relevant information is not fully available (Ebbers \& Wijnberg 2012: 231).

\subsection{Personal and Organisational-Institutional Reputation}

In modern society, not only natural persons are able to acquire reputation but also collective subjects, such as institutions or organisations (Luhmann 1989: 40ff). The most important example is company reputation, which Seemann describes as an intangible asset of a company, as it makes a statement about the evaluation of all stakeholders of a company. This evaluation depends on the cognitive and emotional perception of individual stakeholders and can be influenced by corporate communication (Seemann 2008: 41). Furthermore, Eisenegger found in long-term studies that communication in the media society increasingly relies on personalisation, i.e. organisations are defined by their management staff. This leads to an increased risk of fragility, since the reputation of individual (sometimes only briefly employed) managers is in the foreground and it is becoming increasingly difficult for individual institutions or organisations to establish a consistent reputation (Eisenegger 2005: 41f; Szyszka 2010: 108). In addition, as Ebbers and Wijnberg point out, personal reputation always flows into company reputation (2012: 228). Corporate reputation refers to the credibility, trust, support and respect that relevant stakeholders have for the company, whether they recommend it, or defend it in the event of criticism and thus support it (Wiedmann, Fombrun \& van Riel 2007: 322; cf. Bendixen 2011: 242). Good corporate communication is essential, especially in the cultural sector. It is, therefore, all the more important that all employees internalise the company's values and act accordingly. Otherwise, they endanger the company's positive reputation and, in extreme cases, even its right to exist (Wood \& Rentschler 2003: 529).

It is just as difficult to build a good reputation as it is easy to lose it again (ibid: 530). Building and maintaining a reputation are, therefore, essential tasks of PR.

\subsection{Reputation as a Core Concept in PR}

In the sense of Bourdieu, who considers reputation as social capital (Bourdieu 1983), reputation acts as a confidence-building measure. The public's trust must be strengthened by strategically planned and implemented communication measures; the emergence of mistrust must be prevented and thus the reputation will grow in a positive direction. PR take on this task because it is supposed to position actors and their services as positively as possible. Reputation assumes the function of assigning actors within society to their position and differentiating them from one another. For this reason, reputation management is equated with PR practices. Eisenegger and Imhof point out that reputation is formed face-to-face in personal networks and communication, but at the centre of the constitution of reputation are the media that raise awareness in society with their reporting and thus an image of individual actors, topics or entire companies. In addition, media are increasingly being used by stakeholders-in this case not only the communication departments of cultural establishments but also the ADs themselves-to model their reputation. Regardless of the type of organisation, the media form the centre of modern society and thus also for the constitution of reputation (Eisenegger \& Imhof 2007: 12, cf. Kreutzer 2014: 25ff).

\subsection{Reputation Management in Cultural Enterprises}

A company's good reputation is important in several ways: it contributes to being the first choice for potential customers as well as for employees, suppliers and investors. A high degree of positive reputation also reduces 


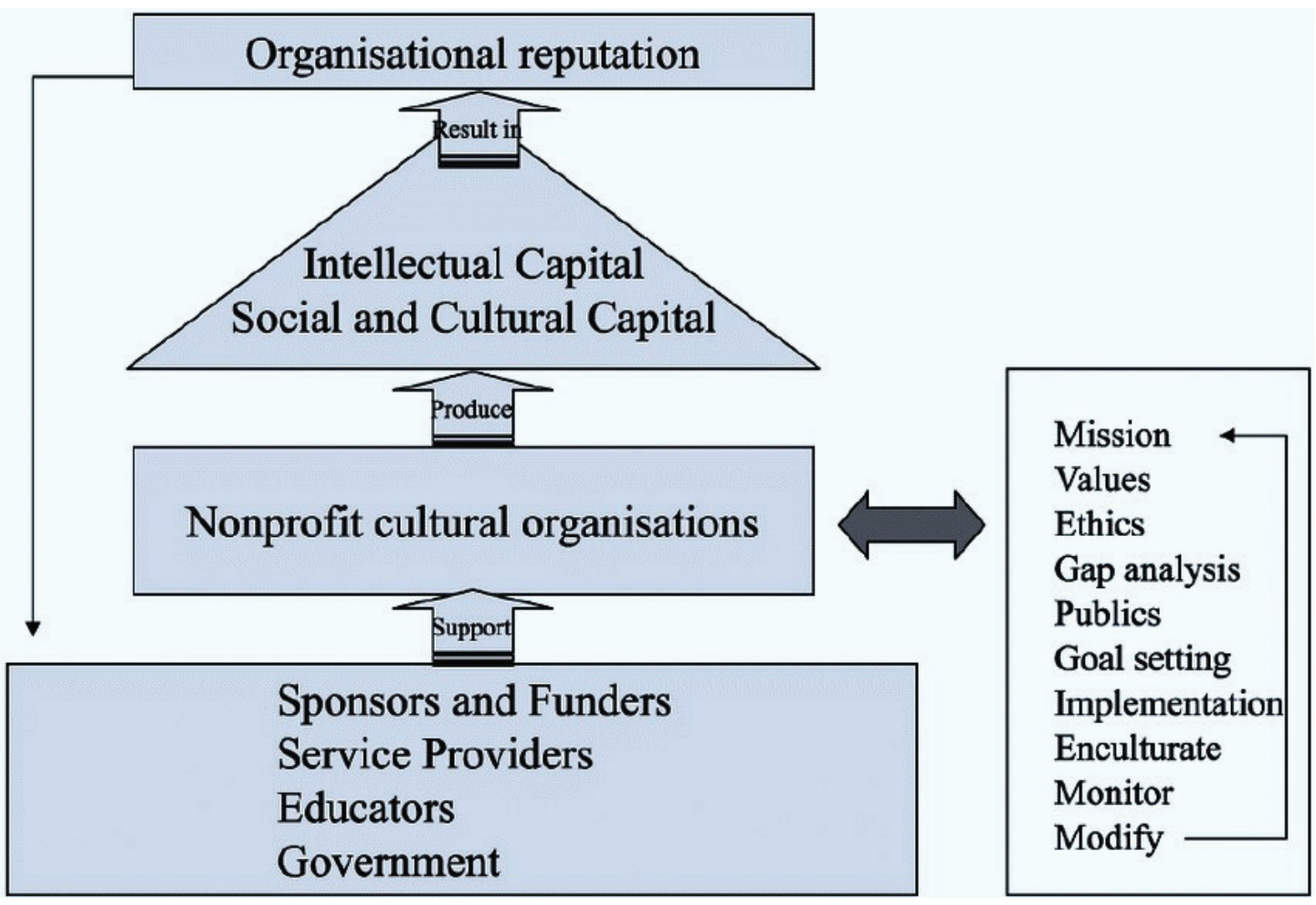

Figure 1. Factors influencing organisational reputation (Wood \& Rentschler 2003).

a company's vulnerability to economic cycles, because customers tend to remain loyal even in difficult situations (Ternès \& Runge 2015: 1).

As stated above, a reputation is extremely beneficial for financing, especially in the cultural sector, where there is always a very high degree of uncertainty with regard to services that will only be provided in the future. In order to weigh up the risks, all stakeholders can fall back on past successes and thus the reputation as a safeguard (Ebbers \& Wijnberg 2012: 230).

Since reputation is very sensitive in its construction, it requires strategic management to build and strengthen it. Building a high reputation takes a lot of perseverance and consistency and, above all, requires strategic planning and implementation in order to achieve long-term success. So, long-term-oriented measures are preferable to short-term actions, as Ternès and Runge explain (2015: 2ff).

\section{Artistic Director}

\subsection{Definition and Tasks}

Artistic directors are the chief executives of arts organizations such as orchestra, opera, dance, and theater companies. In addition to planning and implementing a long-term vision for the company, artistic directors hire performance and production talent, select the season repertoire, and are likely to produce, direct, or conduct themselves. (Berklee 2020)

The term $A D$ defines a management position; the individual leads the enterprise programmatically, takes precedence in artistic matters and thus shapes the artistic profile. He/she uses his/her network to engage artists, use personal press contacts and, in addition to the PR work, through the awareness of its own personality, help position the cultural establishment within the scene and also its finances. In smaller institutions, the AD may also take on commercial or organisational tasks. Aesthetic competence and a comprehensive knowledge of one's own art sector, its historical development and social framework are among the most important requirements for the AD 
(Abfalter 2010: 80f). The AD is supported in its artistic work by other artistic staff, for economic matters, depending on the branch, for example by an administrative director or the commercial management (Hausmann 2019: 17; Koska 2011: 3ff).

The demands on the AD are diverse; so, in addition to typical leadership qualities, they must have determination, assertiveness, business management knowledge and, above all, diplomacy, negotiation and foreign language skills. Abfalter emphasises the qualities of curiosity and enthusiasm, since they respond positively to emotions and also have a charismatic effect, as charismatic leaders can motivate employees to achieve top performance (2010: 80ff; Abfalter \& Hinterhuber 2010).

However, Klein shows that although this personality concept works convincingly, in the reality of cultural establishments, it cannot always apply to all, because many of these postulated characteristics are fundamentally innate and cannot be learned or can only be learned with difficulty. In addition, someone who can demonstrate all of the characteristics listed may tend to have narcissistic personality traits despite or perhaps because of their strong charisma (2013: 33). The narcissistic or 'self-enamoured' leader particularly focuses on the staging of himself/ herself, demands due respect and always wants to be the focus. These extraordinary people can lead a cultural establishment to the desired success through their dynamism but also endanger it through strongly irrational decisions and a tendency to overestimate themselves (Abfalter 2010: 89; Gardner \& Avolio 1998).

\subsection{The AD's Reputation}

Studies by Abbé-Decarroux (1994) and Urrutiaguer (2002) show that the reputation of ADs is of great importance for a cultural establishment. The $A D$ is regarded as a key person and stands for expectations in a performance. As stated, the reputation of organisations is also often associated with individuals. Opera houses are associated with their directors. The bond between staff and the $A D$ is also demonstrably stronger than the bond with the organisation as an employer. Furthermore, reputation is often seen as a substitute for formal qualifications because there are no standardised training paths in the cultural sector. Experience is comparatively more important than in other fields (Abfalter 2010: 256; Herbst 2003b: 183ff).

Another aspect to be critically questioned is the temporary representation. ADs are appointed for a certain period of time and, in addition to the interests of the business, must also represent their personal interests in order to maintain their own personal reputation. It is, therefore, important that the company and AD define a common set of values (Szyszka 2010: 109). Schindler refers to the problem of personalised communication also in sponsorship and the acquisition of funding. Cultural sponsorship, as well as lobbying and communication with decision-makers in public administration, is anchored in the management levels of cultural establishments and often based on personal networks of the AD (Schindler 2013: 139/195f).

With its appearance and communication—internally but above all externally-the AD exerts a significant influence on the perception of the company by stakeholders. The AD's behaviour is observed internally and externally (Seemann 2008: 113f). Precisely for this reason, this personalisation can be problematic for the AD, because there is an increasing tendency in the media to include private topics in the reports (Eisenegger 2005: 67; Könecke 2014: 138). For this reason, PR assumes an immensely important advisory function (Mandel 2012: 179f).

\subsection{Reputation Transfer to the Festival}

As described, important prerequisites for ADs are artistic skills and a network with important contacts within the relevant scene but, above all, their reputation among specialist colleagues (Hagendorf \& Prümke 2003: 94). With the selection of a suitable leader, the transfer of attitudes, credibility and increased attention is also intended. Recipients should transfer their attitudes towards the AD to the company itself. Personal characteristics such as reliability, international recognition and technical skills should be transferred to the company. Hagendorf and Prümke state that the greatest credibility is achieved when the attitudes towards the company and the potential AD are compatible (2003: 94; Herbst 2003b: 183ff). One example is Rudolf Buchbinder, who has been celebrated as an international classical music star for decades and who as $A D$ has been bringing renowned orchestras and musicians to the Lower Austrian periphery since 2005 (Grafenegg Festival). The management of this company and political decision-makers have succeeded in finding a personality with compatible attitudes who embodies reliability and international recognition. 


\section{Music Festival}

\subsection{Definition}

Festival, which goes back to the Latin festivus (solemn, festive) means periodically recurring events that are characterised by the quality of the participating artists and by multi-day or a duration of several weeks (Schaal 1997; Young 1980: 505). There are no limits to the content and staging of the festival. For example, dramaturgical works can be performed at a festival and (contemporary) concerts or readings can be held at special locations. In the second half of the 20th century in particular, festivals in a wide variety of art forms developed; in music, in addition to open-air festivals in the pop and rock scene, there are opera and operetta festivals (Schaal 1997; Young 1980: 507ff).

The typical form of the music festival we know today goes back to the Bayreuth Festival, which Richard Wagner organised in 1876 with the support of King Ludwig II of Bavaria, which served as a model for other festivals such as the Glastonbury Festival in Great Britain (1914) or the Salzburg Festival in Austria (1920) and later also for many jazz, blues and folk festivals (Tschmuck 2020: 148, Scherer, Riklin \& Bieger 2001: 299ff). Young points out that the festival format has increasingly taken on a national or ideological function in the 20th century. For example, the Lucerne Festival came into being in the 1930s against the backdrop of political upheaval, because many artists could no longer perform in Bayreuth or Salzburg, which were under the influence of Nazi Germany (Scherer, Riklin \& Bieger 2001).

At all times, however, it is essential that important artists (star cast) appear and thus bring a quality of artistic performance to places where otherwise only few art and cultural activities are offered (cf. Mandel 2012: 172). The significance, thus, arises particularly from the interaction of artistic, economic and sociological factors.

Within the scope of this paper, the focus should be on festivals of high culture, as described above, in Austria, in order to ensure comparability within approximately the same basic conditions.

\subsection{Cultural Tourism and Regional Development}

Festivals can have an enormous impact on a region and its tourism, as they manage to influence the region's reputation through reputation transfer (Mandel 2012: 172f; Hudson et al. 2015). In this context, indirect return is one of the most frequently used terms. It describes external influences on the economy and employment in the region through the attraction of visitors and tourists. These regions also provide media contributions they would otherwise not be able to achieve. In order to record the economic effects of cultural offers, different methods were borrowed from national accounts and empirical social research. It was found that in addition to classic location factors, agglomeration effects also occur (Abfalter 2010: 52f). This emerges, for example, from a study on the economic significance of the Salzburg Festival from 2011, in which 3,500 festival visitors were surveyed. It shows that the festival is to be seen not only as an artistic but, above all, as an economic engine of the entire region. Thus, the macroeconomic effects of the festival, including the indirect profitability as the main object of the study, are to be distinguished between direct and indirect effects. The primary effects of the festival include, on the one hand, the expenditures made by visitors for accommodation, food, transportation, shopping etc., and, on the other hand, those expenditures directly related to the festival, i.e. for the goods and services purchased as well as personnel expenses (Gaubinger 2011: 7). Furthermore, the study's author notes that within one fiscal period, tax and social benefits generate more revenue for the public sector than it pays in subsidies (ibid. 2011: 1). The result of a spatial incidence analysis designed to determine the economic effects of the Beethovenfest Bonn shows even a multiplier effect of public funding of 4.15: every euro funded thus generated more than 4 euros for the region through direct and indirect inflows (Engelsing \& Müller 2010: 19). Likewise, the indirect profitability survey for Heidelberger Frühling 2016 also shows a comparable result. The city of Heidelberg's subsidies of EUR 810,000 for the festival was accompanied by economic effects of EUR 3.28 million, resulting in a profitability factor of over 4 (4.05) (Gesellschaft für Innovative Marktforschung mbH 2018: 3; cf. Tschmuck 2020: 149).

Another survey conducted by the Salzburg Chamber of Commerce on the economic significance of the Salzburg Festival takes the same line, focusing not only on tangible, monetarily measurable effects such as indirect profitability and regional/supraregional value creation but also on intangible effects such as image effects, demand for education and competence clusters in various sectors (Wirtschaftskammer Salzburg 2017: 7). Examples cited here include tourism providers, transport companies and the media industry, which are part of the 'festival ecosystem' (p. 13). According to Scherer, Riklin and Bieger (2001: 299), this extraordinary contribution of festivals to the sustainable 
branding of destinations can be explained by the fact that recurring events with their precise consistency of permanence also bring about sustainable economic effects that can be added up and long-term network effects (Wirtschaftskammer Salzburg 2017: 13). In a nutshell, on the one hand, a region is culturally vitalised by festivals and, on the other hand, this region becomes even more attractive for tourism and other sectors of the economy (Bendixen 2011: 341).

\subsection{Festival Communication}

The local and regional political considerations just described have led to a festival boom in recent decades (Tschmuck 2020: 149). Other reasons for the increase in the number of new festivals are the change in social values and needs, the trend toward experience and leisure orientation that has been apparent for some time (cf. Opaschowski 1998; Scherer, Riklin \& Bieger 2001: 277) and not least the need for live music triggered by digitalisation as Webster et al. state (2018) and Hitters and Mulder confirm (Hitters 2020). Along with this, Bennett et al., who, in the context of a broad-based study of case studies relating to festivals in Australia and Europe, identified a 'festivalisation of culture' (Bennett, Taylor \& Woodward 2014, cf. Tschmuck 2020: 149).

Above all, the not everyday event character makes the visit to festivals a special experience for supporters, sponsors, media representatives and, of course, the audience (Mandel 2012: 172). The survey on the Beethovenfest Bonn, for example, points out network effects and shows that sponsorship is an important element in corporate communications for main and event sponsors. They want to stand out from other companies and offer concert events with an extraordinary supporting programme, which should benefit their own corporate image. Business partners are invited to meet famous artists or talk to the $A D$ in person. Likewise, for the media, regardless of reporting, advertising cooperation is an important economic factor that is intended to benefit both cooperation partners (Engelsing \& Müller 2010: 16ff). When planning communication measures for a festival, it is, therefore, essential to take all these factors into account. However, since festivals are only designed for a certain duration, they do not have continuous work structures and, therefore, form a special form of cultural enterprise. The structures either have to be rebuilt each time or are carried out in close collaboration (or in connection with) existing cultural establishments with their continuous communication channels (Mandel 2012: 172; cf. also Rowley \& Williams 2008). Thus, the communication has to be strategic and targeted. The artistic profile, which is rounded off by the AD and also by the festival location and a corresponding supporting programme, offers an overall experience, as Prentnice and Andersen describe in their study on creative destinations (2003: 7ff). This overall concept is ideally at the centre of the PR work, with which visitors can identify (Mandel 2012: 172). The communication strategies are adapted to the person of the $A D$ and positioned internationally (Young 1980: 508) in order to make the festival known, to regularly promote the establishment and be able to build on previous successes in the next season (Mandel 2012: 172). Hence, the festival programme, communication and the positive visitor experience go hand in hand.

\section{Success (Performance)}

\subsection{Definition}

Abfalter points out that there is no clear definition for success or performance because the individual goals or results that are adequately interpreted as success differ too much (Abfalter 2010: 197). For example, success in modern societies can be understood in the same way as the claim to power, as we find it with Bourdieu, in terms of indicators such as money, title, prestige or even power that can be seen in assertiveness. Success is then determined in comparison with competitors or earlier results (Neckel 2002: 63).

In daily business life, success describes the result of economic activity in a company during a certain period of time (profit/loss) (Abfalter 2010: 197). Key performance indicators are used to measure success and monitor the achievement of agreed goals (Ridler 2012: 103). It is, therefore, a question of quantitative measurement parameters that represent company processes and structures and thus the relationships between internal and external factors (Abfalter 2010: 207f; Vakianis 2005: 173f). In the cultural sector, however, success has to be examined based on other facets.

\subsection{Measurement}

In the cultural sector, a classic success measurement, which is assessed on the basis of sales, profit, share prices, market shares or return on investment (ROI), does not apply (Abfalter 2010: 197). Financial key figures could even be misleading if one realises that cultural businesses are largely financed by subsidies, sponsoring or private 
donations and that their success could, thus, be presented in a distorted way (Gainer \& Padanyi 2005). Likewise, the basically quantifiable indicator of occupancy is manipulated by giving free tickets to important stakeholders. This figure, therefore, only corresponds to the number of tickets actually sold in a few cases. And a high number of visitors says little about a positive assessment by visitors (Shrum 1991: 372, quoted in Abfalter 2010: 262).

To measure the success of a cultural enterprise with its intangible services, the striving for aesthetics and quality on the basis of key figures would be inadequate (ibid. p. 236). Therefore, Gilhespy has developed a measurement system that takes the specifics of cultural businesses into account (Table 1):

\begin{tabular}{l|l}
\hline 1. & Access maximisation \\
\hline 2. & Attendance maximisation \\
\hline 3. & Diversity/multiculturalism \\
\hline 4. & Economy maximisation \\
\hline 5. & Education \\
\hline 6. & Excellence \\
\hline 7. & Innovation \\
\hline 8. & Revenue maximisation \\
\hline 9. & Service quality maximisation \\
\hline 10. & Social cohesion \\
\hline 11. & Economic importance and impact \\
\hline 12. & Prestige (author's note: reputation!) \\
\hline 13. & Quality of life (Publicness) \\
\hline
\end{tabular}

Table 1. Performance Indicators (Gilhespy 1999: 41ff).

These indicators should be weighted and evaluated in order to implement the special features of cultural institutions in the measurement of success (Gilhespy 1999: 41ff).

\subsection{Reputation as Success Factor}

Cultural establishments evade a quantifiable evaluation of success in many ways. In terms of quality, however, success can primarily be determined in the form of reputation. And this also has an impact on other areas, because a good company reputation affects both artistic aspects and, as already explained, financial resources (Wood \& Rentschler 2003: 530). The reputation of the management level is particularly important in new companies (cultural establishments), which have to be established for both visitors and investors. Investors, in particular, evaluate the performance and reputation of the AD before they donate their money to a cultural company (Ebbers \& Wijnberg 2012: 231). Furthermore, Ebbers and Wijnberg found in their study of the film industry that the director's reputation affects the cast and thus leads to success (2012: 235).

Also, Urrutiaguer states that the reputation of a cultural company 'is usually perceived as the most reliable indicator of quality' (Urrutiaguer 2002: 199), because live performances always involve a certain risk of unpredictability. If an institution has earned a good reputation through excellent performance, excellence will be expected in the future.

Abfalter states that the organisational reputation of a cultural enterprise is also an indicator of the ability to employ special artists (stars) on good terms (2010: 253). The decisive factor here, however, is, above all, the AD, who contributes to the good reputation of the institution (Elberse 2007: 102; Padanyi \& Gainer 2003: 252f):

Artistic careers and artistic prestige are dynamically linked: artists and art institutions derive their prestige from their past successes (trajectories), and their present prestige influences the further course of their careers. In addition, the prestige of artists and institutions are intertwined. Artists derive their prestige at least in part from their affiliations to art organizations, and the prestige of organizations is based on the artists which they are able to take on. (De Nooy 2002: 147f)

Gainer and Padanyi found that a growing artistic reputation also leads to an accumulation of resources and that the reputation of the management level, of the artists involved and of the organisation per se determines how successfully new resources can be acquired (Gainer \& Padanyi 2002). This also confirms the assumption made by Tassie et al., who state that they research the reputation of organisations before they decide to invest (Tassie et al. 1996). 
A high reputation consequently gives a cultural company an advantage over competing companies, increasing its own company value and providing support from stakeholders even in turbulent times (Abfalter 2010: 253). Klein also deals with the role of sponsors, who usually expect a positive effect on their own company through reputation transfer. Conversely, he states that non-profit companies suffer financial losses if their reputation deteriorates. Sponsorship money could be withheld, or subsidies, services or material goods could be cancelled (Klein 2008: 232).

Therefore, it can be inferred that the role of the $A D$ and his reputation make an essential contribution to the success of a cultural enterprise, both from an artistic and from an economic point of view.

\section{Methodology: Expert Interviews}

Although cultural enterprises are confronted with similar problems internationally, the national structures and framework conditions show quite large differences. For this reason, the research focused on festivals in Austria. As shown, quantitative measurement methods should be avoided and instead a qualitative approach was employed. So, to open up the research question, expert interviews were conducted. Experts including artist managers, Chief Executive Officers (CEOs) of cultural enterprises, renowned artists, investors, journalists or politicians were asked about reputation management, with regard to the question to what extent the ADs' reputation impacts the economic and/or artistic performance of cultural enterprises. Standardised guidelines accompanied the interviews (Mayring 2016: 70). The experts were asked to report on how, especially after a change in artistic management, the economic situation of cultural enterprises changed. In particular, they were supposed to also comment on their experiences regarding changes in artistic quality, audiences and indirect return.

\subsection{Experts}

The experts were selected in spring 2020. Unfortunately, out of 26 experts, only 14 agreed to be interviewed (anonymised). Since Austria's cultural scene is very manageable, several experts refused to provide information. After a pilot phase and pretests, the interviews were carried out and prepared for further processing (Table 2).

\begin{tabular}{|l|l|}
\hline E1 & Operative manager \\
E2 & Operative manager \\
\hline E3 & Commercial manager \\
\hline E4 & Commercial manager \\
\hline E5 & Human resources manager \\
\hline E6 & Artist manager \\
\hline E7 & Artist manager \\
\hline E8 & Sponsor \\
\hline E9 & Sponsor \\
\hline E10 & Cultural journalist \\
\hline E11 & State politician \\
\hline E12 & Local politician \\
\hline E13 & Renowned artist \\
\hline E14 & Renowned artist \\
\hline
\end{tabular}

Table 2. Experts interviewed (anonymised representation)

\subsection{Evaluation}

Bogner et al. suggest qualitative content analysis as the optimal form of evaluation when expert interviews are used to obtain information: 'This information may be selective and sometimes contradicting in individual cases (that's why several interviews are conducted), but in principle it is assumed that the expert knowledge is capable to depict the world correctly' (2014: 72). Therefore, a qualitative content analysis according to Mayring is carried out on the basis of the transcribed recordings of the expert interviews. This evaluation model helps to structure the interview text and filter important - related - statements (Mayring 2016: 114ff; Bogner, Littig \& Menz 2014: 72ff). A computeraided evaluation of the expert interviews was carried out in order to use the different display variants (ibid. p. 83). 


\subsection{Results}

Based on the theoretical considerations, hypotheses were formulated and verified by analysing the experts' statements.

\section{\#1: Protagonists in cultural enterprises (i.e. CEOs, heads of communication departments, political decision-makers) pay attention to potential ADs' reputation.}

The evaluation shows that the reputation of potential ADs impacts the application process very early. CEOs and (HR) agents use different channels, networks and personal contacts to get information about future leaders.

Festivals, in particular, are often founded through the initiative of individuals who subsequently take on the artistic direction. When initiators resign, an adequate leader has to be found. Experts state that they use the media to find out about potential candidates, but above all, they also keep track on competing companies. E5 points out that applicants usually send in very extensive references, which means they are aware of the enormous importance of reputation. Also, most of the experts refer to the importance of social media.

Agencies are an important intermediary between artists and companies and are asked for recommendations. Especially when ADs of an agency are committed, more (well-known) artists from this agency are increasingly committed to a festival.

The most important sources are, of course, personal contacts. Experts refer to the fact that the cultural scene in Austria is manageable and cultural practitioners know each other.

As the evaluation of the expert interviews shows, Hypothesis 1 is thus verified: protagonists pay attention to and try to find out about the reputation of potential candidates in media, at agencies, but, above all, within their personal networks.

\section{\#2: Due to their (high) reputation, people are appointed artistic directors in order to have a positive impact on the} success (economic and/or artistic) of cultural enterprises.

As explained in theory, one of the most important prerequisites for a person's reputation is public attention. E6 assumes that particularly well-known ADs generate more interest and attract more people than an unknown individual. And several experts cited Harald Serafin, former AD of the Mörbisch Festival. E1 admits: 'Guests only come to our festival because of the AD!' Also, newly established festivals gain a head start if the AD has a good reputation and a certain level of awareness, because a significant director brings outstanding actors. All experts agree that the AD with a high reputation also attracts other artists with high reputation, which, in turn, has an impact on the success and reputation of the cultural establishment. Ideally, the AD's network can be linked to the festival.

The question of whether special personalities are particularly suitable for the role of AD was largely ignored by the experts, but specific characteristics were identified, such as social skills, authenticity, team spirit or leadership qualities. E1: 'The leadership behavior of the $A D$ is company-building and can motivate or even demotivate the employees.'

Experts perceived changes in the profile with new ADs. Sometimes these changes are also strategically planned. Therefore, communication skills are also considered to be particularly important, as the experts affirm.

In addition to the change in profile, experts also observed changes in the audience structures-in both a positive and a negative direction. E6, E8 and E10 expressly attribute this to the reputation of the AD, and other experts want it to be understood in a more complex way as an 'overall concept' because there are considerably more factors (e.g. financial), touristic parameters or weather conditions.

Hypothesis 2 turns out to be more complex, as it involves different factors. On the one hand, it can be stated that the $A D$ is selected on the basis of reputation, but reputation must be understood as expertise within a professional group and must in no way be reduced to familiarity. ADs bring in their networks and attract other artists of the same rank, which increases the quality of a festival and thus its reputation. The extent to which the AD stages himself in the media depends on the AD's personality. With the help of ADs and their reputation, a festival can gain larger audiences, as well as media presence, which, in turn, can attract more attendees and ultimately has an impact on sales.

\section{\#3: Funders and sponsors pay attention to the reputation of the artistic director when entering into (financial)} commitments. 
As shown, the AD's reputation can serve as a surrogate for previous success. The evaluation of the expert interviews shows that the AD's reputation plays a role for both political funders and sponsors.

In general, not all experts see the acquisition of funding as the primary task of the AD. But, as E3 impressively describes, 'Experience shows renowned ADs are door openers!' And all confirm that ADs with high reputation are definitely beneficial. Furthermore, E8 is addressing the reputation transfer factor: Sponsors expect an improvement of their own reputation for their monetary contribution, as stated by two experts.

The importance of political support is emphasised by most experts. E1, E2 and E3 observe that the reputation of the $A D$ is definitely an important factor for political authorities. E4 attributes particular influence to politics, but this is due to the special constellation that the mayor is also heavily involved in the cultural operations of E4 and the development of the entire region is of particular interest to him. However, E10 also sees risks in the influence of politics, especially when it comes to the appointment or dismissal of the AD, as political authorities sometimes bring about changes that have not been sufficiently reflected and that can have far-reaching and irreversible consequences.

Thus, Hypothesis 3 can be answered affirmatively: (Political) sponsors pay attention to the reputation of ADs. As simple as this may sound, compromises have to be made, because neither can you force an AD to come into direct contact with donors nor should corporate communication be too closely linked to individual people.

\section{\#4: The AD's reputation contributes to the development of an entire region}

As discussed, festivals offer a special atmosphere and attract people to regions that otherwise offer little culture. Also, it is important to adapt the festival's profile to the characteristics of its region. Making the festival a special experience, integrating it into an overall concept, is, therefore, a unique opportunity to revitalise entire regions around festival locations (E4). Retail, gastronomy and hotels are heavily frequented during the festivals, as experts indicated.

Hypothesis 4 should show how the development of a region can be traced back to the reputation of the AD. As explained, this hypothesis can be partially confirmed. For another part of the experts, the context of the entire environment has to be considered.

\section{Discussion: The Power of Reputation}

Classic methods of success measurement do not apply in culture, but it is about attracting as many internal and external stakeholders as possible. The goal is to satisfy the audience, artists, employees, media representatives etc. (Abfalter 2010: 103) and acquire high artistic quality (Bendixen 2011: 266; Ridler 2012: 101). Depending on the expert group, opinions on the subject of success diverge. While sponsors and, in some cases, representatives of politics, despite all considerations about the quality, would particularly like to support those productions that are widely accepted, the other experts see artistic quality as the primary goal.

Selecting ADs with high reputation, who bring outstanding artists, and communicating this strategically can help transfer the AD's positive attributes to the cultural enterprise (Hagendorf \& Prümke 2003: 94) and is often a described aim, as several experts indicate. However, a reputation transfer is not always possible or necessary, especially when the company already has a high reputation. A negative change in the reputation of an $A D$, on the other hand, can also damage the festival's reputation and requires quick reactions.

It should be determined whether certain personality types are more suitable to become ADs. The theory names a varied catalogue of personal requirements such as professional expertise, communication skills or charisma and shows that narcissistic personalities can also bring dynamism to a company in addition to all the risks of selfpresentation. The experts from the field affirm the necessary versatility of an AD, but, above all, agree that, in addition to professional expertise and a good network, social skills are relevant.

The most important partners for an optimally controlled reputation management are media representatives who, with their reports, have a positive influence on the AD's and the company's reputation.

The (positive) impact of ADs on potential investors and critics is repeatedly determined. Especially in the nonprofit sector, scientists see a positive reputation as an essential basis for existence, especially when it comes to convincing sponsors. While some experts follow this line of argument, others do not see sponsor acquisition as the responsibility of Ads. Furthermoresponsors name rather altruistic motives, but of course, also intend reputation 
transfer. And for critics, too, the reputation is an important quality feature for the cultural scene, even though some media representatives can be dazzled by a cleverly staged reputation.

Another aim was to determine to what extent the reputation of the $A D$ affects the development of a region. As stated, thanks to their unusual event character and top-class cast, festivals attract external audiences and bring purchasing power as well as different network and other intangible effects. However, the experts do not agree on this point. While some confirm theoretical theses and report on growth in the number of overnight stays and sales, others point out that there are further factors for the development of regions that are not clearly related to cultural enterprises and/or the ADs' reputation. This discrepancy should be investigated as part of further quantitative research.

In summary, the AD's reputation can have considerable impact on the success of a festival, from an economic and, especially, from an artistic point of view. In the case of negative development, the experts prove what theoreticians like Wiedmann, Fombrun and van Riel (2007: 321) describe: If the AD has an increasingly bad reputation, to avoid damage of the company's reputation, crisis communication or an early termination of cooperation in order to rebuild positive reputation though appropriate action is advisable.

\section{About the author}

After studying musicology at the University of Vienna, Martina Kalser-Gruber gained her first professional experience at the Austrian Broadcasting Corporation and in cultural management before she joined the Department for Arts and Cultural Studies at Danube University Krems. By studying 'Communication and Management' at the Danube University Krems, she deepened her knowledge in communications in the cultural field. Kalser-Gruber completed her studies with a master's thesis on reputation management. Since 2020, she has been in charge of the musicians' bequests at the Archive for Contemporary Arts. Her research focuses on communication, leadership and reputation management in the creative industries as well as contemporary music.

\section{References}

Abbé-Decarroux, F. (1994) "The Perception of Quality and the Demand for Services. Empirical Application to the Performing Arts", Journal of Economic Behavior \& Organization, vol. 23, no. 1, pp. 99-107.

Abfalter, D. (2010) Das Unmessbare messen? Die Konstruktion von Erfolg im Musiktheater, 1st edition, VS Verlag für Sozialwissenschaften, Wiesbaden.

Abfalter, D. \& Hinterhuber, H. H. (2010) "Der Einfluss authentischen Führungsverhaltens auf den wahrgenommenen Erfolg im Kulturbetrieb", in Change Leadership: Den Wandel antizipieren und aktiv gestalten, eds H. Pechlaner, M. Raich, S. Schön \& K. Matzler, Gabler, Wiesbaden, pp. 95-120. https://doi.org/10.1007/978-3-8349-86818_5

Bendixen, P. (2011) Einführung in das Kultur- und Kunstmanagement, 4. Auflage, VS Verlag für Sozialwissenschaften, Wiesbaden.

Bennett, A., Taylor, J. \& Woodward, I. (2014) The Festivalization of Culture. Ashgate. https://doi. org/10.4324/9781315558189

Berklee College of Music (2020) Artistic Director. Available at: https://www.berklee.edu/careers/roles/artistic-director.

Bogner, A., Littig, B. \& Menz, W. (2014) Interviews mit Experten, Eine praxisorientierte Einführung, Springer VS, Wiesbaden.

Bourdieu, P. (1983) "Ökonomisches Kapital, kulturelles Kapital, soziales Kapital”, in Soziale Ungleichheiten. Soziale Welt Sonderband 2, ed. R. Kreckel, Göttingen, pp. 183-198.

Bromley, D. (2002) "Comparing Corporate Reputations. League Tables, Quotients, Benchmarks, or Case Studies?", Corporate Reputation Review, vol. 5, no. 1, pp. 35-51.

De Nooy, W. (2002) "The Dynamics of Artistic Prestige", Poetics, vol. 30, pp. 147-167. https://doi.org/10.1016/ S0304-422X(01)00044-4

Ebbers, J. \& Wijnberg, N. (2012) "The Effects of Having More Than One Good Reputation on Distributor Investments in the Film Industry", Journal of Cultural Economics, vol. 36, no. 3, pp. 227-248.

Eisenegger, M. (2005) Reputation in der Mediengesellschaft. Konstitution - Issues Monitoring - Issues Management, VS Verlag für Sozialwissenschaften, Wiesbaden. 
Eisenegger, M. \& Imhof, K. (2009) "Funktionale, soziale und expressive Reputation - Grundzüge einer Reputationstheorie". in Theorien der Public Relations: Grundlagen und Perspektiven der PR-Forschung, ed. U. Röttger, VS Verlag, Wiesbaden, pp. 243-264.

Eisenegger, M., Imhof, K. (2007) "The True, the Good and the Beautiful: Reputation Management in the Media Society. fög discussion paper 2007-0001", Fög-Forschungsbereich Öffentlichkeit und Gesellschaft.

Elberse, A. (2007) "The Power of Stars: Do Star Actors Drive the Success of Movies?", Journal of Marketing, vol. 71, no. 4, pp. 102-120.

Engelsing, L. \& Müller, M. (2010) Studie über die wirtschaftlichen Effekte des Beethovenfestes Bonn im Jahr 2009. Edited by DHPG Dr. Harzem \& Partner KG, Bonn.

Fombrun, C. (1996) Reputation: Realizing Value from The Corporate Image. Harvard Business School Press, Boston.

Fombrun, C. J., Gardberg, N. A. \& Sever, J. M. (2000) "The Reputation Quotient SM: A Multi-Stakeholder Measure of Corporate Reputation", Journal of Brand Management, vol. 7, no. 4, pp. 241-255.

Gardner, W. L., Avolio, B. J. (1998) "The Charismatic Relationship. A Dramaturgical Perspective", Academy of Management Review, vol. 23, no. 1, pp. 23-58.

Gaubinger, B. (2011) Die wirtschaftliche Bedeutung der Salzburger Festspiele. Studie 2011 des Zentrums für Zukunftsstudien der Fachhochschule Salzburg.

Gesellschaft für Innovative Marktforschung mbH (2018) Der wirtschaftliche Effekt des Heidelberger Frühlings. Resultate einer Umwegrentabilitätsstudie aus dem Jahr 2016. Heidelberg. Available at: https://www. presseportal.de/pm/43317/3889349.

Gainer, B., Padanyi, P. (2002) "Applying the marketing concept to cultural organisations: An empirical study of the relationship between market orientation and performance", International Journal of Nonprofit and Voluntary Sector Marketing, vol. 7, pp. 182-193. DOI: 10.1002/nvsm.178.

Gainer, B., P. (2005) "The Relationship Between Market-oriented Activities and Market-oriented Culture: Implications for the Development of Market Orientation in Nonprofit Service Organizations", Journal of Business Research, vol. 58, pp. 854-862. DOI: 10.1016/j.jbusres. 2003.10.005.

Gilhespy, I. (1999) "Measuring the Performance of Cultural Organisations: A Model", International Journal of Arts Management, vol. 2, no. 1, pp. 38-52.

Hagendorf, J., Prümke, A. (2003) "Imagetransfer zwischen Marken und Prominenten", in Der Mensch als Marke. Konzepte - Beispiele - Experteninterviews, ed. D. Herbst, Business Village, Göttingen, pp. 93-117.

Hall, R. (1992) "The Strategic Analysis of Intangible Resources", Strategic Management Journal, vol. 13, no. 2, pp. 10-17.

Hausmann, A. (2019) Cultural Leadership. Begriff, Einflussfaktoren und Aufgaben der Personalführung in Kulturbetrieben, Springer VS, Wiesbaden.

Herbst, D. (2003a) Der Mensch als Marke. Konzepte - Beispiele - Experteninterviews, Business Village, Göttingen.

Herbst, D. (2003b) Zehn Thesen zu „Der Mensch als Marke“, in Der Mensch als Marke. Konzepte - Beispiele Experteninterviews, ed. D. Herbst, Business Village, Göttingen.pp. 161-180.

Hitters, E. \& Mulder, M. (2020) "Live Music Ecologies and Festivalisation: The Role of Urban Live Music Policies", International Journal of Music Business Research, vol. 9, no. 2, pp. 38-57.

Hoffjann, O. (2015) Public Relations. UVK Verlagsgesellschaft mbH, Konstanz.

Hudson, S., Roth, M. S., Maden, T. J. \& Hudson, R. (2015) "The Effects of Social Media on Emotions, Brand Relationship Quality, and Word of Mouth: An Empirical Study of Music Festival Attendees", Tourism Management, vol. 47, Apriol 201, pp. 68-76.

Klein, A. (2008) Besucherbindung im Kulturbetrieb: Ein Handbuch. Springer-Verlag, Wiesbaden.

Klein, A. (2013) "Von der „verwalteten Kultur" zum „Leadership" in Kultureinrichtungen”, in Erfolgsfaktor Mitarbeiter. Wirksames Personal-management für Kulturbetriebe. 2, eds. A. Hausmann, L. Murzik, Springer VS, Wiesbaden:, , pp. 25-38.

Könecke, T. (2014) Das Modell der personenbezogenen Kommunikation und Rezeption. Beeinflussung durch Stars, Prominente, Helden und andere Deutungsmuster, Springer Gabler, Wiesbaden.

Koska, D. (2011) "Das Traumpaar. Doppelspitzen in Kultureinrichtungen," in Kulturmanagement \& Kulturpolitik, eds. F. Loock \& O. Scheytt, Dr. Josef Raabe, Stuttgart, pp. 1-14.

Kreutzer, R. (2014) Corporate Reputation Management in den sozialen Medien, Springer Gabler, Wiesbaden. Luhmann, N. (1989) Vertrauen. Ein Mechanismus der Reduktion sozialer Komplexität. Enke, Stuttgart. 
Mandel, B. (2012) PR für Kunst und Kultur: Handbuch für Theorie und Praxis, 4th edition, Transcript, Bielefeld. Mayring, P. (2016) Einführung in die qualitative Sozialforschung, 6th edition, Beltz Verlag, Weinheim/Basel.

Neckel, S. (2002) "Ehrgeiz, Reputation und Bewährung. Zur Theoriegeschichte einer Soziologie des Erfolgs", in Lebenszeiten. Erkundungen zur Soziologie der Generationen, eds. G. Burkart \& J. Wolf, VS Verlag für Sozialwissenschaften, Wiesbaden, pp. 103-117.

Opaschowski, H. W. (1998): "Vom Versorgungs- zum Erlebniskonsum: Die Folgen des Wertewandels", in Eventmarketing: Grundlagen und Erfolgsbeispiele, ed. O. Nickel, Vahlen, München, pp. 25-38.

Padanyi, P. \& Gainer, B. (2003) "Peer Reputation in the Nonprofit Sector Its Role in Nonprofit Sector Management", Corporate Reputation Review, vol. 6. https://doi.org/10.1057/palgrave.crr.1540204.

Prentnice, R. \& Andersen, V. (2003) "Festival as Creative Destination," Annals of Tourism Research, vol. 30, no. 1, pp. 7-30. https://doi.org/10.1016/S0160-7383(02)00034-8.

Ridler, G. (2012) Privat gesammelt - öffentlich präsentiert. Über den Erfolg eines neuen musealen Trends bei Kunstsammlungen. Transcript Verlag, Bielefeld.

Rowley, J. \& Williams, C. (2008) "The Impact of Brand Sponsorship of Music Festivals", Marketing Intelligence \& Planning, vol. 26, no. 7, pp. 781-792. https://doi.org/10.1108/02634500810916717.

Schaal, Richard.."Musikfeste und Festspiele.” In Laurenz Lütteken (Ed.), MGG Online (2016-). Article first published 1997. Retrieved from https://www.mgg-online.com/mgg/stable/12525.

Scherer, R., Riklin, F.-M. \& Bieger, T. (2001) Die langfristigen Effekte von Kulturevents: das Beispiel von LUCERNE FESTIVAL, in Tourism Growth and Global Competition: International Association of Scientific Experts in Tourism (AIEST): Kongressdokumentation des 51st Congress 2001, eds. P. Keller \& T. Bieger, pp. 277-304.

Schindler, S. (2013) Unerhörte Kultur. Kulturbetriebe in der Kommunikationsflut, Springer VS, Wiesbaden.

Seemann, R. (2008) Corporate Reputation Management durch Corporate Communications, Cuvillier Verlag, Göttingen.

Shrum, W. \& Wuthnow, R. (1988) "Reputational Status of Organizations in Technical Systems", American Journal of Sociology, vol. 93, no. 4, pp. 882-912.

Shrum, W. (1991) "Critics and Publics. Cultural Mediation in Highbrow and Popular Performing Arts", The American Journal of Sociology, vol. 97, no. 2, pp. 347-375.

Szyszka, P. (2010) "Personalisierung und CEO-Positionierung. Theoretische Reflexion eines Praxisproblems", in Personalisierung der Organisationskommunikation. Theoretische Zugänge, Empirie und Praxis, eds. M. Eisenegger \& S. Wehmeier, VS Verlag für Sozialwissenschaften, Wiesbaden, pp. 91-113.

Tassie, B., Murray, V., Cutt, J. \& Bragg, D. (1996) "Rationality and Politics: What Really Goes on When Funders Evaluate the Performance of Fundees?", Nonprofit and Volontary Sector Quaterly, vol. 25, pp. 347-363.

Ternès, A. \& Runge, C. (2015) Reputationsmanagement. Manager und Führungskräfte, Springer Gabler, Wiesbaden. Tschmuck, P. (2020) Ökonomie der Musikwirtschaft, Springer VS, Wiesbaden.

Urrutiaguer, D. (2002) "Quality Judgements and Demand for French Public Theatre," Journal of Cultural Economics, vol. 26, pp. 185-202. https://doi.org/10.1023 A:1015696816657.

Vakianis, A. (2005) Duales Controlling: am Beispiel des Kulturbetriebes „Theater“. Studienverlag, Innsbruck.

Webster, E., Brennan, M., Behr, A., Cloonan, M. \& Ansell, J. (2018) Valuing Live Music. The UK Live Music Census 2017, Available at: https://livemusicexchange.org/resources/valuing-live-music-uk-live-music-census-report2017-emma-webster-matt-brennan-adam-behr-and-martin-cloonan-with-jake-ansell-2018/

Wiedmann, K., Fombrun, C. J. \& van Riel, C. B. (2007) Reputationsanalyse mit dem Reputation Quotient, in Handbuch Unternehmenskommunikation, eds. M. Piwinger \& A. Zerfaß, Gabler Verlag, Wiesbaden, pp. 321-337.

Wirtschaftskammer Salzburg (2017) "Salzburger Festspiele. Motor für die Wirtschaft, Exzellenz-Infusion für den Standort. Wertschöpfungsanalyse der Salzburger Festspiele" Salzburg.

Wood, G. \& Rentschler, R. (2003) "Ethical Behaviour: The Means For Creating and Maintaining Better Reputations in Arts Organisations", Management Decision, vol. 41, no. 6, pp. 528-537.

Young, P. M. (1980): "Festival", in The New Grove Dictionary of Music \& Musicians, ed. S. Sadie, Macmillan Publishes Ltd., London, pp. 505-510. 